\title{
Reflections on the Creation and Implementation of Voting System Guidelines
}

Donetta Davidson and Tom Wilkey

Abstract For some, it may be difficult to remember a time when we had no electronic voting equipment-no scanners accepting paper ballots, no touch screens-whereas the voting system today is the result of decades of work by federal agencies and groups of election officials about voting systems and technology. We participated in these efforts over several decades in different roles over time. This case reflects our observations and experiences about how the current certification system came to be, and reflections about how improvements can be made.

Keywords National Association of Election Directors • Election Center • Voting system guidelines

D. Davidson

United States Election Assistance Commission, Silver Spring, MD, USA

Colorado Secretary of State, Denver, CO, USA

T. Wilkey $(\bowtie)$

United States Election Assistance Commission, Silver Spring, MD, USA

New York State Board of Elections, New York, NY, USA

(C) The Author(s) 2019

M. Brown et al. (eds.), The Future of Election Administration, Elections, Voting, Technology, https://doi.org/10.1007/978-3-030-18541-1_3 


\section{The Role of NASED}

One of the keys to the current certification system is the role played by NASED, the National Association of State Election Directors. Formed in 1989 , NASED is the national professional association of state chief election officials in the states, the District of Columbia, and the US territories. Both of us were involved in the formation of this group, and both served as one of its presidents during the early years (Donetta in 1994 and Tom in 1996). Around this time, it had also become obvious that standards would be needed for electronic voting equipment that was already in use and beginning to become more widely popular. The idea of standards had been discussed for about a decade, including a study commissioned by the Federal Election Commission (FEC), and its report in 1983 from the National Clearinghouse on Election Administration (housed within the FEC) that performance standards for voting systems were necessary.

NASED's role in standards began during conversations with the FEC as the federal agency was developing standards, which were published in 1990. NASED agreed to serve as the certifying agency for the new voting system standards. This meant developing the first handbook for voting system accreditation, which NASED did in 2001. It also meant accrediting a number of testing laboratories, and these were initially known as Independent Testing Authorities (ITAs), then voting system testing laboratories (VSTLs). The labs that were accredited evolved from labs that had been involved in similar work for the federal government.

During this time, the Election Center also played a key role. The Election Center is the only organization established for training election administrators and other election professionals. It offers professional certification through its Certified Elections Registration Administrator (CERA) program, which is operated in partnership with the Auburn University Graduate Program in Election Administration and its Master of Public Administration program. When NASED agreed to take on responsibility for voting system certification, it set up an Accreditation Board. The Election Center stepped in to assume the role of secretariat for NASED and the Board. These links provided election officials with a ready-made opportunity to share information widely across the Election Center membership, which reached local election officials and others in the election community who were not members of the national associations of state election directors or secretaries of state, NASED or NASS (the National Association of Secretaries of State). The Election Center continued as the NASED secretariat for more than 25 years, until 2018. 
In 2002, the Help America Vote Act (HAVA) transferred responsibilities of the National Clearinghouse on Election Administration out of the FEC to the newly formed Election Assistance Commission (EAC). Related to voting systems, the EAC was tasked with the responsibility of developing new voting system standards that would now be known as voluntary voting system guidelines (VVSG), and implementing a national testing and certification program for voting system hardware and software. HAVA established a new set of administrative groups around voting system standards that replaced the functions that NASED had performed and expanded their reach. These included the Standards Board, the Board of Advisors, and the Technical Guidelines Development Committee (TGDC). The Standards Board has 110 members: 55 state election officials are selected by their respective chief state election official and 55 local election officials are selected through a process supervised by the chief state election official. The Board of Advisors has 35 members who are appointed by various organizations of state officials related to election operations, including NASED and the Election Center. The TGDC has 15 members including the chair chosen by the National Institute of Standards and Technology (NIST) and the other members chosen by NIST and the EAC.

Both of us were involved quite a bit during the transition to the EAC and afterward. Tom was appointed in 2005 as the first executive director of the EAC, and Donetta was appointed in 2005 as a Commissioner, and Donetta chaired the TGDC during her tenure; both stepped down in 2011.

\section{The Help America Vote Act}

When the Help America Vote Act (HAVA) was adopted in 2002, it created a situation where things were actually backwards if what we wanted were modern voting systems that satisfied a set of national standards. Instead of beginning with the creation of the first set of VVSG standards and requirements, and getting those out so that manufacturers could build the equipment, the approach was to tell everyone they had to have new equipment by a certain day. States in turn bought old, legacy equipment that some states are still using today.

At the time, there was a conflict between accessibility and moving away from old punch card type machines. The law was clear and had more about accessibility than security. At NIST there was an expert on accessibility, and there was another expert on the disability community on the TGDC. Together they pushed for accessibility to be a part of HAVA so 
that every voter could vote independently without any help. That was clear from the beginning of the creation of HAVA because it had to be done.

During the development of HAVA, it seemed like direct recording electronic (DRE), touch screen machines, would be better for accessibility. The activists were sure that they were not secure or accurate. The press picked up on this immediately and influenced the public's understanding of the DRE machines. Many counties went to paper ballots as a way to protect themselves from bad press and public opinion. Paper activists could be fairly aggressive at times. A few years ago, Donetta came out to observe one of the election audits in Colorado. When asked why she voted years ago not to require paper when Colorado uses paper today, Donetta remarked that some states had laws that allowed them to buy equipment that didn't use paper. She didn't want those states to be forced to buy entirely new systems. Further, at the time, the procedures and rules for handling paper were not secure across the states and counties.

\section{THE TGDC}

The TGDC faced several challenges including forming its membership and starting up a process. Both of these would be easier today because something is already in place, but at the time the structure was just a shell. At the EAC, we fought for a vendor to be on the TGDC, though a lot of people did not like that. But we thought we needed at least one vendor. Ed Smith was on the committee for the TGDC to represent all of the vendors, and he did a good job representing the entire community, not the particular vendor he worked for.

The process for developing the rules for equipment through the TGDC was hard and took a long time. We found that NIST had extensive knowledge, and that just blew us away. It was also challenging because it was easy for technical experts to talk over your head. They are scientists and work on testing on all kinds of things from rockets to election systems. It took a great deal of time for experts and election officials to find common ground on how to talk about things, and this improved over time.

There was one conversation about bar codes that was quite controversial. Election Systems and Software (ES\&S) actually got caught putting bar codes on the ballot that related to the voter. The activists on the committee were up in arms about this. One advocate proved that she could track someone down to the voter name through the bar codes. ES\&S changed this obviously, but bar codes are still controversial. They are still allowed, but cannot be used in ways that track them to the voter. 
Part of the reason that creating the VVSG standards took so long at first was because we had to develop the process. Now each stage takes less time because the process is already in place. At one point, we had standards ready but we couldn't adopt them because we didn't have a quorum. Once they got a quorum, the commissioners decided to add more things before adopting them, which created an even longer delay. They did this because technology had changed, and then the new ideas had to go back to the Standards Board for approval. There is also a comment period, and additional time was added because of the federal Paperwork Reduction Act. The Paperwork Reduction Act was created before the widespread use of computers and requirements still applied at the time that caused delays.

The EAC timing for certifying equipment also took a long time at first. Some of what looked like delay on the part of the EAC was really due to the approaches taken by the vendors. Equipment vendors were bringing in equipment for testing before even testing it themselves and, not surprisingly, problems would be found. As a consequence, we at the EAC published a certification chart that showed the different stages of the process and how much time each took. This allowed observers to see that what looked like an EAC delay was in part because the vendor had to go back and correct problems which took them months to fix. Now vendors are so much better about checking all of their equipment and testing it before the equipment goes in for federal testing.

There is a vendor committee now, as well as an activist committee. NIST and TGDC members come to those meetings so everyone can hear them. The process has improved by having these groups involved. The TGDC is small and not much of its work is open to the public-they can come, but there are no comments from the audience. So it's important to have these committees and to listen to what the people on the committees have to say. This gives more input which helps the process.

The Advisory Board has not been very manageable because there are so many people on it. The Board has become wiser about how they do things, working in subcommittees, because when the whole committee is all together, the people with the loudest voices have the room. The representation on this is also important. In some states the Secretary would go, but if the Secretary wasn't that involved in the election side of the work in that state, the Secretary would send a staff member. This works in some cases, but not in others. And the rules require that no state can have two members of the same political party, so that also affects who is on the Board. 


\section{Choosing New Equipment}

Today, election system manufacturers will often have a variety of machines so they can work with the different demands from the states. These demands emanate from state law, the preferences of the procurement officials and preferences of the public. In addition, some states require certification from both the EAC and the state office. This costs vendors almost double. Some states like California have even more rigid testing standards. Certification costs are paid by the vendors and can be significant; the certification cost depends on how long it takes the system to be certified. The cost can range usually from $\$ 50,000$ to $\$ 500,000$, though in one case it went as high as one million. Small changes to state laws can cost the vendor about $\$ 50,000$ in certification costs for each occurrence.

State associations are also involved in the equipment selection and certification process. Some states have strong associations and others do not. When Colorado Secretary of State Wayne Williams wanted to adopt a new system, he pulled in the activist community, the county clerks who are the elected officials responsible for running elections, and the county commissioners. These groups all had the opportunity to weigh in on the vendors and give their opinions. Some of the vendors listened to the opinions of these groups, and some did not. This is what graded some of the vendors down in this process. Some of the counties tested these systems and we watched that process. Each state manages its voting system selection process differently. Some secretaries of state get very involved in this and have strong opinions; in other states, local election officials have more say.

\section{Conclusion}

The national VVSG system has taken more than 30 years to develop to this point, and the entire voting system environment is entering a new phase. The states are looking at new equipment to replace the systems purchased with HAVA funds; virtually every system has ended its useful life in one way or another. New trends are coming, with the use of commercial equipment such as iPads and ePollbooks, and new processes like ballot on demand where voters are issued onetime use access cards that are activated to the voter's ballot style. With new methods come new and easier ways to assist all types of voters with disability. Security is also a concern in a new way, now that election systems are part of the US critical infrastructure. What we have seen through the development of this system, from the 
earliest stages with NASED, is that the election community continues to operate in a way that incorporates the information from technical experts along with the experiences and opinions of election officials who use these systems. From our experiences and observations, it would not have been possible to develop our current system without the many critical conversations that brought forward the input of local and state election officials.

Open Access This chapter is licensed under the terms of the Creative Commons Attribution 4.0 International License (http://creativecommons.org/licenses/ by $/ 4.0 /$ ), which permits use, sharing, adaptation, distribution and reproduction in any medium or format, as long as you give appropriate credit to the original author(s) and the source, provide a link to the Creative Commons licence and indicate if changes were made.

The images or other third party material in this chapter are included in the chapter's Creative Commons licence, unless indicated otherwise in a credit line to the material. If material is not included in the chapter's Creative Commons licence and your intended use is not permitted by statutory regulation or exceeds the permitted use, you will need to obtain permission directly from the copyright holder.

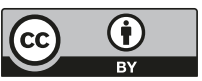

